\title{
No-Cost Learning Material: Perspectives From Industrial and Systems Engineering Students
}

\author{
Lin Li \\ Kennesaw State University \\ Robert S. Keyser \\ Kennesaw State University \\ Raven Pierson \\ Kennesaw State University
}

Affordable Learning Georgia (ALG) is an initiative that began in 2014, which supported faculty when transforming their previously required textbooks to low-cost, no-cost textbooks. The goal was to help reduce the financial burden on students in their pursuit of a college education. In this study, the researchers developed no-cost textbooks for two undergraduate industrial and systems engineering courses. Both quantitative and qualitative measures are used to assess the effectiveness of the textbook transformation and students' experience of no-cost learning material in the Industrial and Systems Engineering program. The responses were overwhelmingly positive with respect to the no-cost textbooks in both courses.

Keywords: affordable learning Georgia, no-cost textbooks, open educational resources

\section{INTRODUCTION}

The rising cost of physical textbooks has created a demand for low-cost, no-cost electronic textbooks, or e-Books, and other learning materials for students. Since 2013, the University System of Georgia has supported the development and course offerings of low-cost, no-cost learning resources through their Affordable Learning Georgia (ALG) transformation grants. The ALG supports the Open Educational Resources (OER) defined as "teaching, learning and research materials that make use of appropriate tools, such as open licensing, to permit their free reuse, continuous improvement, and repurposing by others for education purposes" by the United Educational, Scientific and Cultural Organization (UNESCO).

Given the limited OER resources available for Industrial and Systems Engineering (ISYE) program, the researchers participated in Round 16 of the Affordable Learning Georgia grants and developed two separate no-cost electronic textbooks in the Industrial and Systems Engineering department at Kennesaw State University, one for the ENGR 1100 course (Survey of Engineering Applications from Mathematics) and the other for the IET 4451 (Systems Simulation) course, to replace previously required textbooks purchased by students. The learning material will be hosted on OpenALG (https://alg.manifoldapp.org/). Student survey feedback responses at the conclusion of the initial offerings of these electronic textbooks 
during Fall 2020 semester was overwhelmingly positive, which may serve as an impetus for other faculty in the College of Engineering to follow suit.

In this IRB-approved (Institutional Review Board) study, both quantitative and qualitative measures are used to assess the effectiveness of the textbook transformation and students' experience of no-cost learning material in the Industrial and Systems Engineering (ISYE) program. The no-cost learning materials for the two ISYE undergraduate engineering courses were developed in Summer 2020. These newly developed learning materials were subsequently used during Fall 2020 to replace previously required textbooks for each course. A survey was conducted at the conclusion of Fall 2020 semester to assess student perceptions of the new no-cost textbook as well as their previous experiences with no-cost learning materials. Both quantitative and qualitative measures are analyzed to assess the effectiveness of the textbook transformation and students' experience of no-cost learning material in the Industrial and Systems Engineering program. The quantitative measures include course average GPA, student Drop/Fail/Withdraw (DFW) rates, and student success in course learning objectives. The qualitative analysis is based on a survey we developed to collect students' feedback on the learning materials used in the courses. In addition to rating their experience using a 5-point Likert scale ( $1=$ strongly disagree, and $5=$ strongly agree), students are also given the opportunity to enter any comments they may have. The responses were overwhelmingly positive with respect to the no-cost textbooks in both courses.

\section{LITERATURE REVIEW}

A review of the literature reveals common themes, particularly, with regard to textbook affordability. Other themes, however, relate to how social justice is impacted by textbook affordability, the relationship between a college bookstore and e-Books, the role of the librarian in assisting faculty with selecting Open Educational Resources (OER) for use in their courses, both faculty and student perceptions of the use of OER materials, student success with low-cost, no-cost textbooks, and the impact of these learning resources on student retention.

Morris (2019) notes that student debt at graduation in 2018 was $\$ 1.5$ trillion among 44 million borrowers, with textbooks costs from less than $\$ 100$ to several hundred dollars, depending on the program of study. In an earlier study, Baum et al. (2014) cite that, on average, students spend more than $\$ 1,000$ a year on textbooks. Meinke (2013) notes that textbooks costs rose by an average of $6 \%$ per year over the last decade and the U.S. Government Accountability Office (2013) calculated that textbook costs rose by $82 \%$ from 2002 to 2012, which was triple the inflation rate. Popken (2015) notes that textbook prices increased four times faster than the inflation rate in the past decade and by an alarming 1,045\% since 1977, causing many students to forego the purchase of required textbooks for their courses (Bookboon, 2012; Kingkade, 2011). Martin et al. (2017) notes that $66 \%$ of 676 student survey responses at Brigham Young University have not purchased a textbook due to cost. In another survey conducted at Old Dominion University, approximately $1 / 3$ of student responses indicated that they decided not to purchase required textbook materials due to cost and approximately $1 / 5$ of student responses indicated that they had received a lower grade than expected in a course because they could not afford to cost of course materials. Furthermore, the survey revealed that many students either dropped or withdrew from courses due to the cost of course materials. Activists are now calling on newly-elected President Biden to carry through on his campaign pledge to forgive up to $\$ 10,000$ in student debt per borrower (Holland and Tanzi, 2021; Schirmer, 2020).

To address the needs of historically underserved groups, Jenkins et al. (2020) advocates for greater institutional commitment to the use of OER and other no-cost course materials in addition to further research that explores the social justice implications of OER and textbook affordability. In a recent decomposition study, Kakar et al. (2019) suggests that student loan use accounts for between 3\%-7\% of the

Black-White wealth gap across the wealth distribution in the U.S.

OER transformation projects have a direct impact on the sale of textbooks at college bookstores. Bell (2017) suggests that academic librarians are eager to demonstrate their leadership in such projects by building better relationships with bookstore personnel, such as establishing stronger channels of 
communication, exploring new ways in which libraries and bookstores can work together, and taking the initiative to engage in discussions and find common ground.

Librarians are playing key roles in OER transformation grants. For example, to counter rising textbook prices, Rokusek and Cooke (2019) suggest that library e-books would provide a free, convenient option for students. Moreover, despite the limited availability of suitable e-books, the potential for increased adoption could be attained if librarians would target their advocacy of library e-books to professors who teach lowerlevel courses. At colleges, such as Sinclair Community College, librarians participate in OER grant initiatives and provide individualized consulting, training, and faculty support. Katz (2019) suggests that OER offers new opportunities for librarians to maximize their skill sets by helping faculty to discover OER and other options available for both cost savings to students and improved pedagogy for faculty. When the Affordable Learning Georgia (ALG) initiative began in 2014, Gallant (2015) notes that a pilot team of University System of Georgia (USG) libraries set the strategy and goals of the ALG initiative and identified stakeholders who needed to be engaged, and then talked to stakeholders across the country.

Regarding faculty perceptions of OER, in a 2019 Textbook Affordability Survey sponsored by Taylor $\&$ Francis Group, according to responding librarians, 19 percent of faculty currently work with library staff to reduce textbook costs and nearly two-thirds of librarian respondents reported the number is growing (Peet, 2020). In another survey conducted at the University of the South Pacific (USP), Prasad and Usagawa (2014) report that nearly half of the 39 USP teachers were willing to develop OER derived custom-built textbooks for their courses. Martin et al. (2017) cites $91 \%$ of 573 faculty survey responses at Brigham Young University would be willing to use OER materials and that $53 \%$ of them would welcome assistance in discovering suitable materials for their courses. Harley et al. (2009) report that the Student Public Interest Research Groups (Student PIRGs) launched a two-year campaign in 2007 to drive mainstream faculty's acceptance of open textbooks and other affordable learning resources.

In a survey about student perceptions of open textbooks, Everard and St. Pierre (2014) discovered that over $90 \%$ of students surveyed viewed an open textbook as a comparable or better option than a traditional textbook. In a cross-campus survey conducted at City University of New York (CUNY), student responses indicated an overwhelming positive experience with using Zero Textbook Cost (ZTC) courses due to using no cost textbook, ease of materials access, and that they felt it was better for learning versus traditional textbooks (Brandle et al., 2019). In a survey of college-aged students from over eight universities in the eastern United States, results indicated that generally favorable student perception of OER resources were attributed to factors such as a preference for lower education costs, a preference for online courses, connectivity to the course, and a likelihood to rate faculty members higher (Fine and Read, 2020). In a different study conducted at five state university campuses in California in 2010, of the 662 returned student questionnaires among 33 courses, more than $1 / 3$ of the students were satisfied with eTextbooks, more than one-half of student responses indicated the ease of use of eTextbooks, and that students aged 22 and older tended to have more positive experiences with eTextbooks than younger students (Baek and Monaghan, 2013). In contrast, Benoit (2018) notes that nearly 66\% of student responses in a study conducted at Lethbridge College indicate a preference for printed textbooks, even though $76 \%$ of those student responses identified as in the 18-24 age group, citing students' value in familiarity, convenience, and ease of use when reading printed materials. For those students who preferred digital textbooks, cost consideration was the primary motivator. In a study at Central Washington University, students were given the option of purchasing a textbook or using OER materials to complete their general education requirements. Those who opted for OER course materials were pleased to enjoy some financial relief; however, for those who opted to purchase textbooks, their biggest complaint was that faculty only used very small portions of expensive required textbooks (Valentino and Hopkins, 2020).

Regarding student success, Croteau (2017) notes in a study of twenty-nine Round 1 of the University System of Georgia's (USG) Affordable Learning Georgia (ALG) transformation grant proposals during Spring 2015, survey results indicated that the ALG initiative helped students save money $(\sim \$ 760,000)$ without negatively impacting learning outcomes (i.e., final exam grade, assessment grade, and course distribution of letter grades) between pre- and post- textbook transformation. 


\section{METHODOLOGY}

Developing, adopting and revising no-cost learning material is a process which involves continuous improvement as shown in Figure 1. The effectiveness of the textbook transformation and students' experience of no-cost learning material are collected using an online survey that was created using Qualtrics XM and then administered to students in both courses at the end of the Fall 2020 semester to gauge whether their experience level with no-cost textbooks, their preference to no-cost textbooks versus traditional textbooks, their satisfaction with no-cost learning materials, and responses to an open-ended question soliciting feedback on their experience with these no-cost textbooks. At the end of the survey period, Qualtrics XM generates a report with all responses. To interpret the responses, descriptive statistics generated by Qualtrics XM are used to analyze the answers to a 5-point Likert scale (1=strongly disagree, and $5=$ strongly agree) questions while the answers to the free-response questions are used to provide more detailed conclusions for the researchers.

\section{FIGURE 1}

PROCESS FLOW OF DEVELOPING NO-COST LEARNING MATERIAL

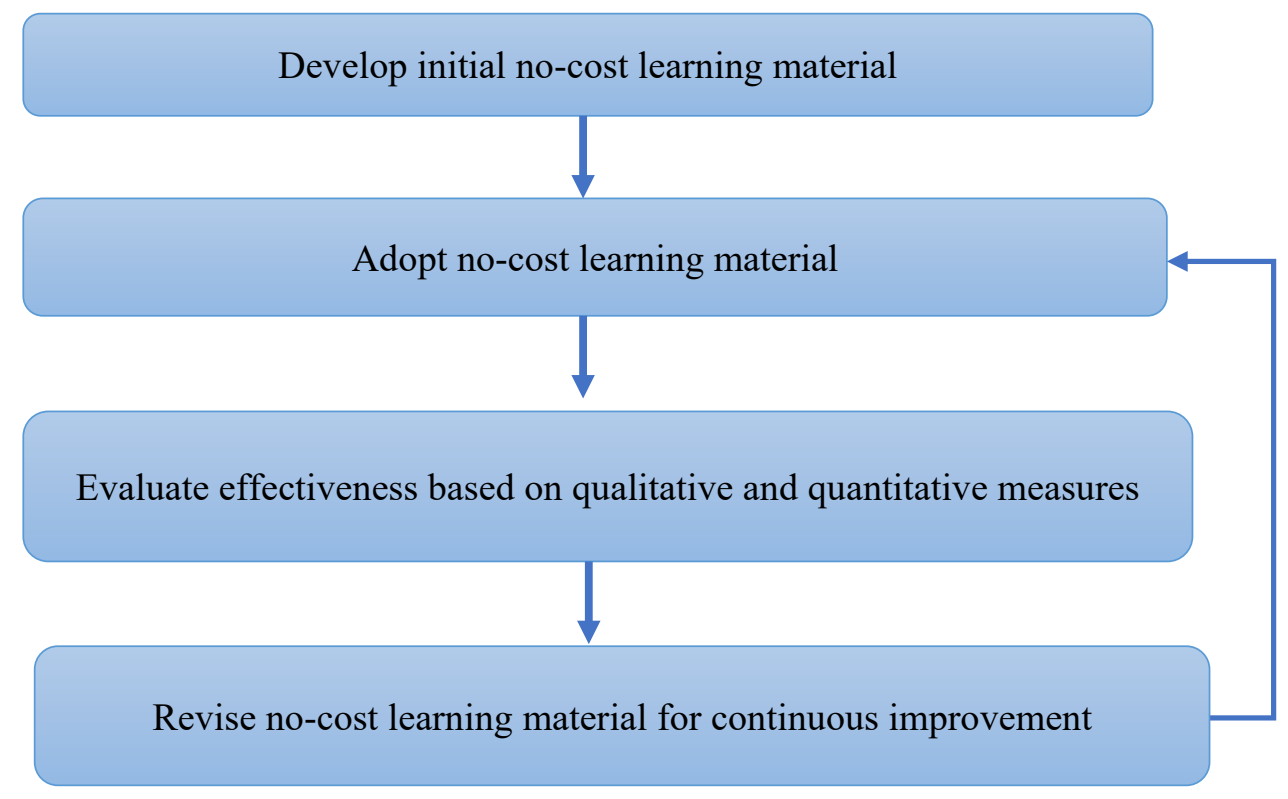

\section{RESULTS AND DISCUSSIONS}

Qualitative and quantitative results are obtained from this study based on students' course performance and class survey on student's perception of no-cost learning material after the adoption of these material. The survey topics include the students experience with no cost material, the preferences of the students, and the feedback given by the student.

\section{Participant Demographics}

The survey was taken by 25 Industrial and Systems Engineering students enrolled in ENGR 1100 and IET 4451 in Fall 2020. There are two different sessions of each course: Hybrid section and Online section. The course modality for hybrid section involves both face-to-face instructions as well as an online component, whereas the online section contains only virtual online format. Figure 2 shows the percentage of students enrolled in each section among those who participated in the course survey. About $46 \%$ of participants are from ENGR 1100 and around 54\% are from IET 4451. Figure 2 indicates more students from online section took the survey compared to the those enrolled in hybrid section with a ratio of 7 to 3 . 
This is consistent with the course enrollment pattern for online section vs. hybrid section with more students prefer online course modality due to the COVID-19 pandemic in Fall 2020.

The participants' age group by course modality is shown in Figure 3, where younger students (ages 1827) are more prevalent in the hybrid sections, older students (ages 28 and older) are more prevalent in the online sections. The online sections, offering more schedule flexibility, tend to be more appealing to older age group students are more likely working either part-time or full-time while taking classes.

\section{FIGURE 2 \\ PERCENTAGE OF PARTICIPANTS ENROLLED IN EACH COURSE SECTION}

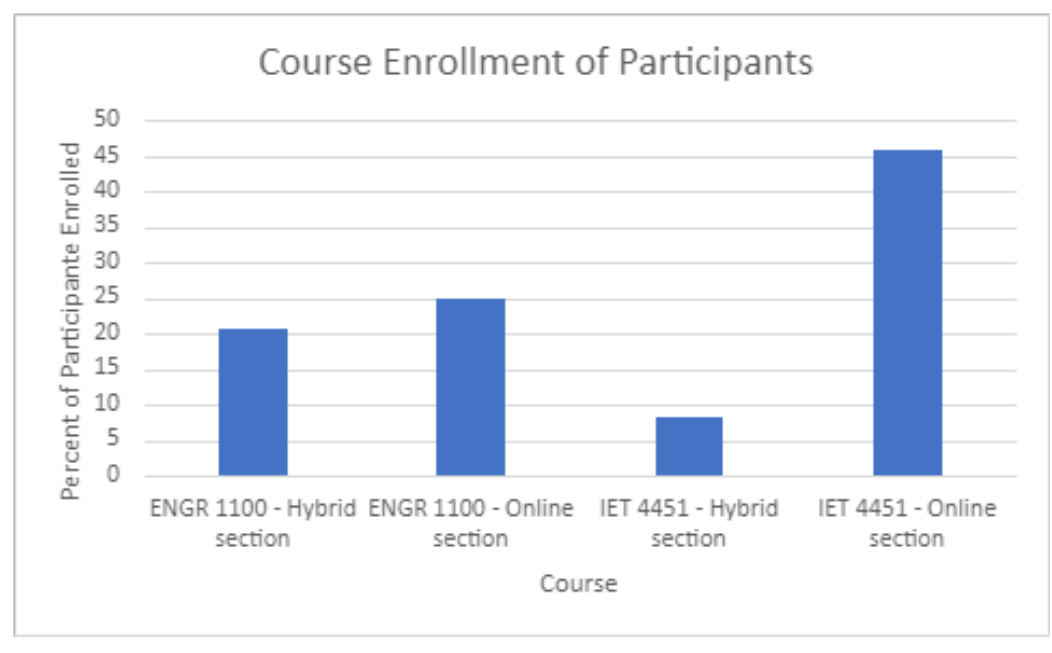

FIGURE 3

PARTICIPANT AGE GROUPS

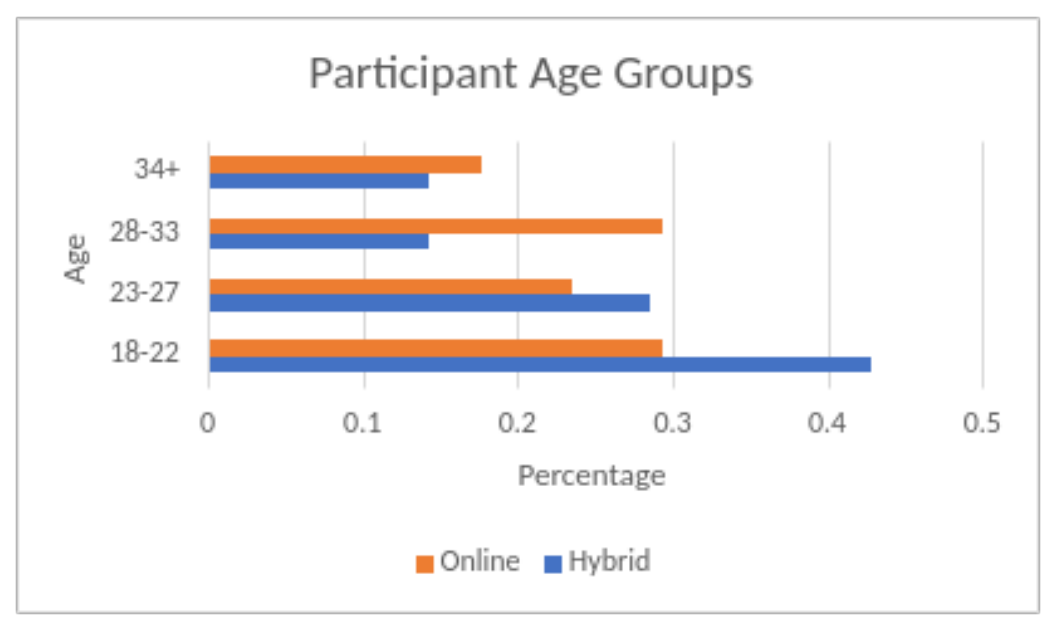

We also look at the ethnicities of the survey participants. Figure 4 indicates $44 \%$ of participants classified as White/Caucasian, followed by a tie at 16\% for both Black/African American and Asian/Asian American.

\section{Participant Experiences With No-Cost Materials}

We also assess the students' prior experience with no-cost learning materials from the two ISYE courses. Even though the OER materials for Industrial and Systems Engineering are limited, some students have had experience with OER learning material in general education courses or in other disciplines. Figure 
5 shows that about $60 \%$ of respondents indicate the use of several no-cost textbooks previously, $16 \%$ of respondents indicated this was their first experience using no-cost textbooks and $24 \%$ of respondents indicated that this was their second experience with no-cost textbooks. Since our project is the first effort of textbook transformation within ISYE program at our university, the $60 \%$ of participants who had previous experience with no-cost textbook courses are mostly taking those courses either in other institutions (for transferred students) or in other departments within our university.

\section{FIGURE 4 \\ ETHNICITIES OF SURVEY PARTICIPANTS}

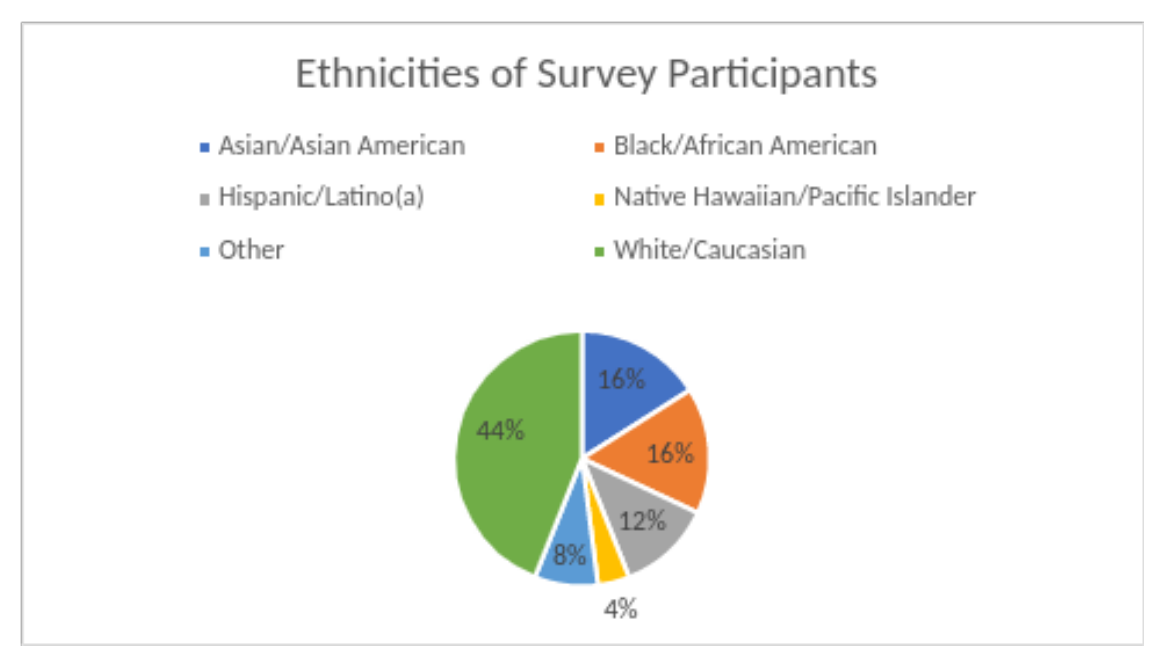

\section{FIGURE 5 \\ STUDENTS' PRIOR EXPERIENCE WITH NO-COST LEARNING MATERIAL}

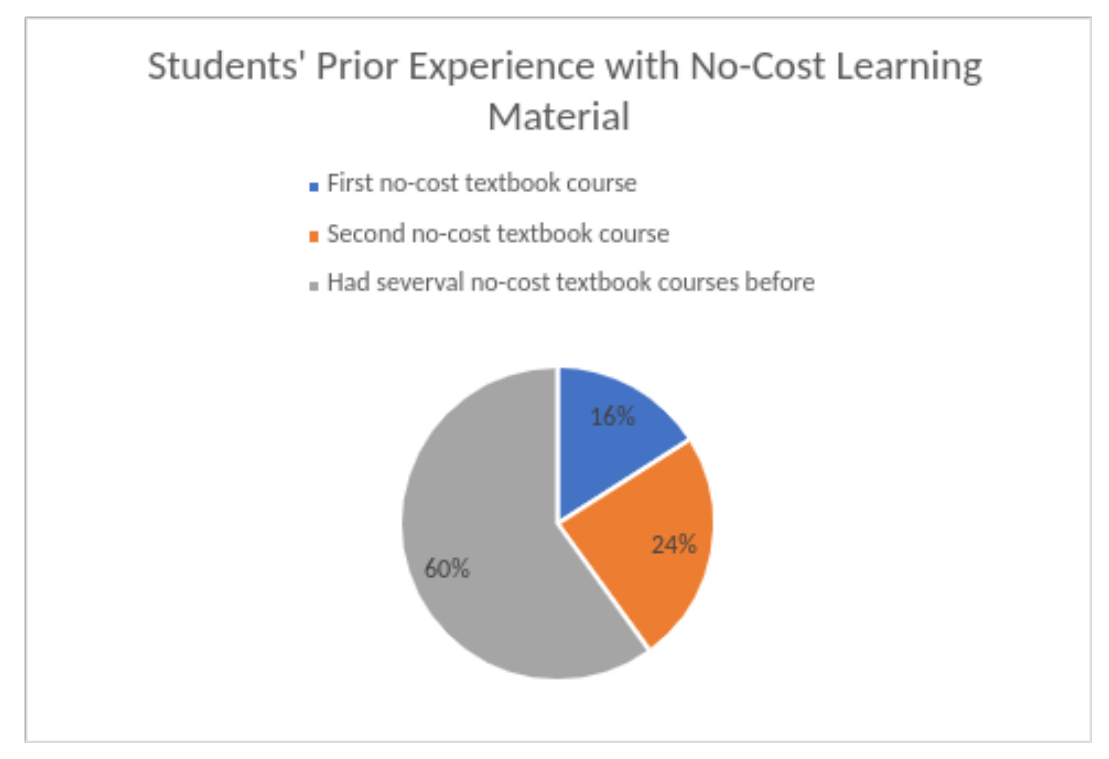

As part of the survey, all participants were asked questions related to their preferences and overall experience with no-cost learning materials. As shown in Figure 6, over 70\% of respondents prefer no-cost textbooks, particularly regarding Industrial and Systems Engineering courses. Nearly $70 \%$ of respondents found the no-cost textbooks written by their professor to be easier to read and understand than traditional textbooks. This may be attributed to both the professor including real-world experiences, rather than 
hypothetical examples, in the no-cost textbook and the fact that the professor is readily available to discuss any material in the no-cost textbook. Additionally, over $40 \%$ or respondents preferred not having a textbook for their course.

\section{FIGURE 6 STUDENT PREFERNCES ON NO-COST LEARNING MATERIAL}

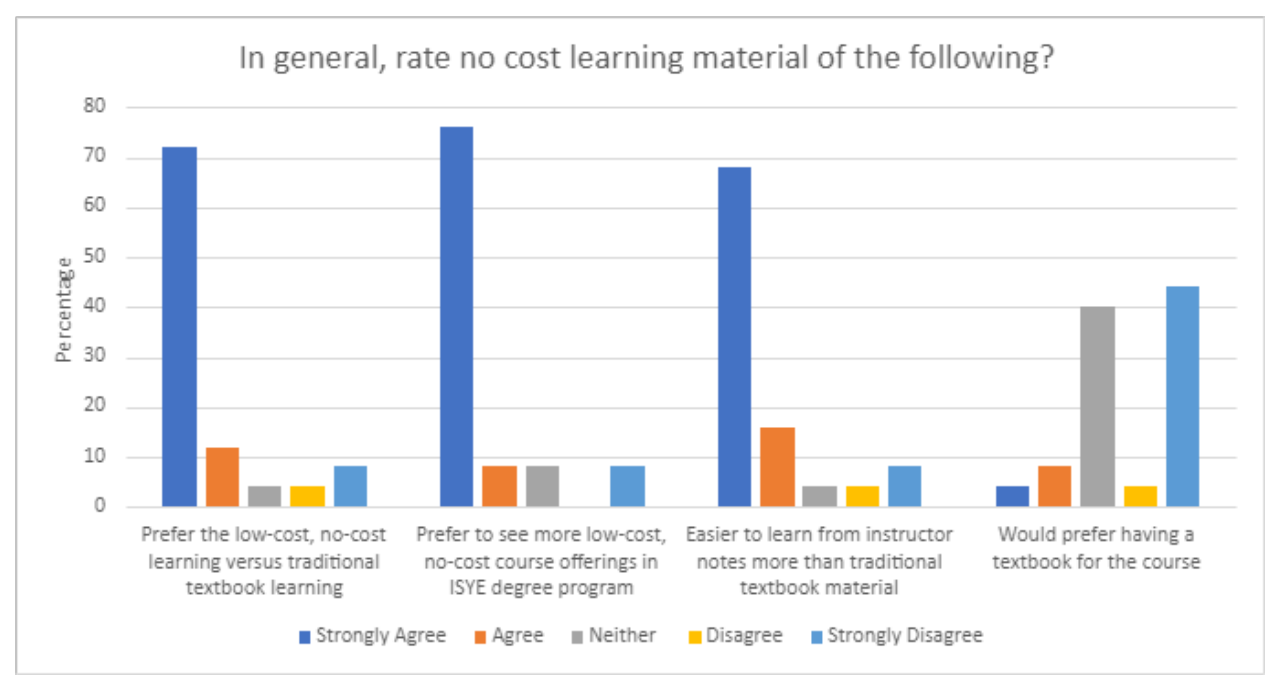

In addition to evaluating students' preference of no-cost learning material vs. traditional textbook, survey questions are also conducted on students' satisfaction level. Table 1 shows a list of comments related to participant satisfaction with no-cost learning materials. The results summarized in Table 2 indicate the average students' feedback based on a 5-point Likert scale ( $1=$ Strong Disagree, and 5=Strong Agree). Both results show overwhelming positive responses to student satisfaction of no-cost textbooks for both ENGR 1100 and IET 4451.

TABLE 1

STUDENT SATISFACTION OF NO-COST LEARNING MATERIALS

\begin{tabular}{|l|l|}
\hline \multicolumn{1}{|c|}{ Which of the following do you strongly agree with? } & Percent of Participants \\
\hline $\begin{array}{l}\text { I was satisfied with the quality of the no-cost materials provided in } \\
\text { this course. }\end{array}$ & $84 \%$ \\
\hline $\begin{array}{l}\text { The no-cost materials in this course helped ease my financial burden } \\
\text { as I pursue my college degree. }\end{array}$ & $88 \%$ \\
\hline $\begin{array}{l}\text { I would recommend to other students that taking a course with low- } \\
\text { cost, no-cost materials provide the same or better quality of } \\
\text { education versus taking a course with traditional textbook materials. }\end{array}$ & $92 \%$ \\
\hline $\begin{array}{l}\text { I wish additional courses in my major offered low- cost, no-cost } \\
\text { materials. }\end{array}$ & $92 \%$ \\
\hline $\begin{array}{l}\text { I believe that going from traditional textbooks to low- cost, no-cost } \\
\text { materials in an industrial engineering course is the way of the future } \\
\text { in higher learning. }\end{array}$ & $84 \%$ \\
\hline
\end{tabular}


TABLE 2

STUDENT FEEDBACK ON NO-COST LEARNING MATERIALS

Statement
\begin{tabular}{|l|c|c|c|}
\hline $\begin{array}{l}\text { I was satisfied with the quality of the no-cost materials provided in this } \\
\text { course. }\end{array}$ & 4.91 & 4.77 & 4.83 \\
\hline $\begin{array}{l}\text { The no-cost materials in this course helped ease my financial burden } \\
\text { as I pursue my college degree. }\end{array}$ & 4.91 & 4.77 & 4.84 \\
\hline $\begin{array}{l}\text { I would recommend to other students that taking a course with low } \\
\text { cost, no cost materials provide the same or better quality of education } \\
\text { versus taking a course with traditional textbook materials. }\end{array}$ & 5.00 & 4.69 & 4.83 \\
\hline $\begin{array}{l}\text { The content, links and other learning module materials were sufficient } \\
\text { to help me learn. }\end{array}$ & 4.82 & 4.84 & 4.84 \\
\hline $\begin{array}{l}\text { Ifeel that learned more in this course using the instructor's low-cost, } \\
\text { no-cost materials included in this course versus using traditional } \\
\text { textbook materials. }\end{array}$ & 4.36 & 4.00 & 4.17 \\
\hline
\end{tabular}

The Based on our assessment data, the no-cost learning materials we developed are as effective as the textbooks used previously in the corresponding courses. The average GPA for ENGR 1100 during the Fall 2020 semester using no-cost learning material is 3.45 compared to 3.28 of the previous semesters using traditional textbook. Similarly, the average student GPA for IET 4451 has improved 5\% in Fall 2020 compared to the semester using traditional textbook. The drop and withdraw rate for both courses are slightly higher in Fall 2020 where the no-cost material is adapted. The failure rate stays similar. The overall comparative impact on student performance in terms of learning outcomes and grades are positive, especially given the impact of COVID-19 on students' performance through the new norm of virtual learning.

Towards the end of the survey, the participants were given the opportunity to voice their opinions on their overall experience with no-cost learning materials and provide some constructive feedback. Many students were thrilled that this method was financially beneficial. This would allow for students to allocate funds elsewhere as opposed to the purchase of textbooks. College is expensive and so are books. Therefore, this method of learning is very favorable among college students and alleviates the stress of purchasing textbooks. Students also thought the instructor-constructed notes were quite easy to follow and learn from. At times, the notes were easier to comprehend than the textbook and these learning materials provide students with their instructors' expertise on the subject matter. Some of students' remarks includes,

"I think this no-cost learning material is quite efficient and help to reduce the costs needed to purchase a textbook that can be allocated elsewhere. This teaching method also allows the instructor to understand and identify areas where students are having difficulty."

"For this course, my instructor's lectures and course notes were much easier to understand than Arena textbook (which I rented virtually due to cost)."

"We appreciate this approach financially, but it also is a better way for us students to learn I believe as well."

\section{DISCUSSIONS AND CONCLUSIONS}

An analysis of ISYE student perspectives reveals that the most important aspects of no-cost learning material, in addition to being cost-effective, also includes the quality of material to enhance the learning of 
each student. The quality of content, such as learning concepts and objectives, are extremely important as this is what the student must comprehend to eventually pass the class. The organization of the learning modules are also a vital component to quality. Learning modules that present material in a consistent, structured manner allows the student to easily navigate through the course to find materials. If the learning materials were made accessible, the student can retrieve course materials with any smart device such as a phone, tablet, or computer with internet access. This is much more convenient for the student than a traditional textbook.

Some students learn better with a physical textbook versus online supplemental material. Therefore, it was suggested that a low-cost printed version of instructor notes be offered. Every student has a different learning style, and we must be open to tend to each student's needs so that they can be successful in any course in which they enroll. Some students also believe that no matter the circumstance, a textbook should be offered and recommended. This will be used as an additional resource, as well as a reference source post-graduation. Textbooks, whether traditional or no-cost textbooks, do hold valuable information and, therefore, will always be a great resource.

Students made clear that they look forward to the no-cost learning material alternative. Instructors should be encouraged and motivated to go the extra mile to make the material informative, interesting, and exciting for the students. Some course material can be quite difficult to learn and might not be very enjoyable at times. For the students to be engaged in the material, the instructors do play a huge role in achieving this for the student to succeed in the course. The ability for the no-cost textbook to enhance the learning of students is critical. Providing additional resources to the students such as links, articles/publications, and other learning modules, help students retain more information of the subject matter beyond the main concepts that are presented in each learning module, which provides an additional opportunity for students to better understand the material. As most of the student feedback agreed, the instructor's course materials and tutorial videos helped them get a better understanding of the concepts rather than simply reading a traditional textbook. This made for a more enjoyable learning experience for the students.

Both ENGR 1100 and IET 4451 course material involves hands-on programming skills (MATLAB for ENGR 1100, and ARENA for IET 4451). From instructors' perspective, developing learning materials by ourselves enables us to better adapt to the evolving and dynamic nature of programming field. New and advanced techniques can be quickly embedded into the ISYE curriculum, such as simulation-regression proposed by Li et al. (2010) and agent-based simulation models (Zhou et al. (2021a); Zhou et al.(2021b)), which are important to the success of Industrial and Systems Engineering students. At the same time, effective transformation activities require significant efforts from the instructors. The success of this project not only benefit students in both ISYE and IET program, but also increases the visibility of ALG in ISYE department.

\section{ACKNOWLEDGEMENTS}

We wish to thank Affordable Learning Georgia, round 16, for the opportunity to participate in this research grant. We also would like to thank our students for participating in the survey that led to our conclusions.

Journal of Higher Education Theory and Practice Vol. 21(10) 2021223 


\section{REFERENCES}

Baek, E-O., \& Monaghan, J. (2013). Journey to textbook affordability: An investigation of students' use of textbooks at multiple campuses. The International Review of Research in Open and Distance Learning, 14(3), 1-26.

Baum, S., Ma, J., \& Bell, D. (2014). Trends in college pricing. College Board, p.44.

Bell, S. (2017). What about the bookstore? Textbook affordability programs and the academic library-bookstore relationship. College and Research Library News, 78(7), 375-377.

Benoit, A.M. (2018). Textbook affordability and student acceptance of textbooks: An institutional case-study. The Canadian Journal for the Scholarship of Teaching and Learning, $9(2)$. Retrieved from https://ir/lib.uwo.ca/cjsotl_rcacea/vol9iss $2 / 3$

Bookboon. (2012). 9 out of 10 students find textbooks too expensive. Retrieved January 22, 2021, from https://bookboon.com/blog/2012/09/the-big-bookboon-textbook-survey-read-the-opinion-ofalmost-10-000-students/

Croteau, E. (2017). Measures of student success with textbook transformations: The Affordable Learning Georgia initiative. Open Praxis, 9(1), 93-108. https://doi.org/10.5944/openpraxis.9.1.505

Everard, A., \& St. Pierre, K. (2014). A case for student adoption of open textbooks. Journal of the Academy of Business Education, 15, 66-76.

Fine, M., \& Read, H. (2020). Factors impacting student perception of open educational resources. $e$ Journal of Business Education \& Scholarship of Teaching, 14(1), 151-173.

Gallant, J. (2015). Librarians transforming textbooks: The past, present, and future of the Affordable Learning Georgia initiative. Georgia Library Quarterly, 52(2), Article 8. Retrieved from https://digitalcommons.kennesaw.edu/glq/vol52/iss $2 / 8$

Harley, D., Lawrence, S., Acord, S.K., \& Dixson, J. (2010). Affordable and open textbooks: An exploratory study of faculty attitudes. Research \& Occasional Paper Series: CSHE.1.10, p.21. Center for Studies in Higher Education.

Holland, B., \& Tanzi, A. (2021, January 11). The battle over student debt. Bloomberg Businessweek, 4684, 22-24.

Li, L., Sourirajan, K., \& Katircioglu, K. (2010). Empirical methods for two-echelon inventory management with service level constraints based on simulation-regression. In Proceedings of the 2010 Winter Simulation Conference (pp. 1846-1859). IEEE.

Jenkins, J.J., Sanchez, L.A., Schraedley, M.A.K., Hannans, J., Navick, N., \& Young, J. (2020). Textbook broke: Textbook affordability as a social justice issue. Journal of Interactive Media in Education, 1(3), 1-13. https://doi.org/10.5334/jime.549

Kakar, V., Daniels, G.E., Jr., \& Petrovska, O. (2019). Does student loan debt contribute to racial wealth gaps? A decomposition analysis. The Journal of Consumer Affairs, 53(4), 1920-1947. DOI: $10.111 /$ joca. 12271

Katz, S. (2019). Leveraging library expertise in support of institutional goals: A case study of an open educational resources initiative. New Review of Academic Librarianship, 25(2-4), 381-391. https://doi.org/10.1080/13614533.2019.1630655

Kingkade, T. (2011, November 10). Rising costs force students to skimp on textbooks. Huffington Post.

Martin, T.M., Belikov, O.M., \& Hilton, J., III. (2017). Analysis of student and faculty perceptions of textbook costs in higher education. Open Praxis, 9(1), 79-91. https://doi.org/10.5944/openpraxis.9.1.432

Meinke, B. (2013). Report released by U.S. GAO demonstrates the need for open textbooks. Retrieved from http://creativecommons.org/weblog/entry/38569

Morris, L.V. (2019). Contemplating open educational resources. Innovative Higher Education, 44, 329 331. https://doi.org/10.1007/s10755-019-09477-7

Peet, L. (2020). Faculty textbook affordability survey. Library Journal, 145(2), 10. 
Popken. (2015). College textbook prices have risen 1,041 percent since 1977. NBC News. Retrieved January 22, 2021, from www.nbcnews.com/feature/freshman-year/college-textbook-prices-haverisen-812-percent-1978-n399926/

Prasad, D., \& Usagawa, T. (2014). Towards development of OER derived custom-built open textbooks: A baseline survey of university teachers at the University of the South Pacific. The International Review of Research in Open and Distance Learning, 15(4), 226-246.

Rokusek, S., \& Cooke, R. (2019). Will library e-books help solve the textbook affordability issue? Using textbook adoption lists to target collection development. The Reference Librarian, 60(3), 169181. https://doi.org/10.1080/02763877.2019.1584597

Schirmer, E. (2020). Drowning in debt. The Nation, 311(12), 14-27.

U.S. Government Accountability Office, Report to Congressional Committees. (2013). College textbooks (GAO-13-368). Retrieved from https://www.gao.gov/assets/660/655066.pdf

Valentino, M., \& Hopkins, G. (2020). No textbook cost general education pathway: An effort to increase retention at Central Washington University. Reference Services Review, 48(3), 503-522. DOI: 10.1108/RSR-03-2020-0015

Walsh, A.J. (2020). Removing barriers: Textbook affordability and OER at Sinclair Community College. Reference Services Review, 48(3), 385-396. DOI: 10.1108/RSR-03-2020-0011

Wittkower, L.R., \& Lo, L.S. (2020). Undergraduate student perspectives on textbook costs and implications for academic success. Open Praxis, 12(1), 115-130. https://dx.doi.org/10/5944/openpraxis.12.1.1036

Zhou, Y., Nikolaev, A., Bian, L., Lin, L., \& Li, L. (2021a). Investigating transmission dynamics of influenza in a public indoor venue: An agent-based modeling approach. Computers \& Industrial Engineering, 157, 107327.

Zhou, Y., Li, L., Ghasemi, Y., Kallagudde, R., Goyal, K., \& Thakur, D. (2021b). An agent-based model for simulating COVID-19 transmissions on university campus and its implications on mitigation interventions: a case study. Information Discovery and Delivery. 